\title{
The Shifting Origins of International Law
}

\author{
Ignacio de la Rasilla ${ }^{\oplus}$
}

\begin{abstract}
Both state-centrism and Euro-centrism are under challenge in international law today and this double challenge, this work argues, is being fruitfully mirrored back into the study of the history of international law. It examines, in the first section, the effects of the rise of positivism as a method of norm-identification and the role of methodological nationalism over the study of the history of international law in the modern foundational period of international law. This is extended by an examination of how this bequeathed a double exclusionary bias regarding time and space to the study of the history of international law as well as a reiterative focus on a series of canonical events and authors to the exclusion of others such as those related to the Islamic history of international law. In the second section, the analysis turns to address why this state of historiographical affairs is changing, specifically highlighting intra-disciplinary developments within the field of the history of international law and the effects that the "international turn in the writing of history" is having on the writing of a new history of international law for a global age. The conclusion reflects on some of the tasks ahead by providing a series of historiographical signposts for the history of international law as a field of new research.
\end{abstract}

Key words: History of international law; Eurocentrism; state-centrism; Inter-disciplinarity; global perspectives.

\section{Introduction}

The dominant realist and idealist approaches ${ }^{1}$ to writing the Western history of international law have a number of elements in common. ${ }^{2}$ First, they are predominantly

\footnotetext{
$\oplus$ Lecturer in Law, Brunel Law School (Brunel University London). Visiting Research Fellow, Lauterpacht Research Centre for International Law, University of Cambridge \& Visiting Research Fellow, Max Planck Institute for European Legal History, Frankfurt (Spring-Summer, 2014) as grantee of the British Academy/Leverhulme Trust and the Max Planck Society. The author is grateful to the Santander/Doha Collaborative Research Grant Program of the Institute of Global Law and Policy at Harvard Law School and to the Brunel University Seminar Research Series.ignaciodelarasilla@post.harvard.edu

1 See also M. Koskenniemi, "Histories of International Law: Dealing with Eurocentrism" (2011) 19 RgRechtsgeschichte 152, 161. The term "idealist or doctrinal histories" indicates, according to Koskenniemi, those histories of international law that "focus on lawyers and philosophers and view the past through debates about legal principles or institutions". By "realist" narratives, reference is made, by contrast, to those histories "that concentrate on State power and geopolitics and view international law's past in terms of the succession of apologies for State behaviour" and periodize accordingly.

2 Besides their "reductionism"; see, in more detail, M. Koskenniemi, "Histories of International Law: Significance and Problems for a Critical View" (2013) 27.2. Temple International Law and Comparative Law Journal, 215, 219.
} 
Ignacio de la Rasilla "The Shifting Origins of International Law' 28 Leiden Journal of International Law 3

(Forthcoming, 2015) (Author's unedited versión - please refer to the published version) (C)

Eurocentric narratives of the history of international law in the sense that they are embedded in a historical macro-narrative according to which "international law is the product of a process initiated in the Western world," ${ }^{3}$ the first stage of which was "the disintegration of the medieval European community into a European society". ${ }^{4}$ Such a European society, and its international-regional legal order would, in subsequent stages, spread out to the four corners of the Globe in the wake of different waves of discovery, war, conquest and colonization led by European powers. Second, the idealist and realist approaches share a deeply state-centric approach to the history of international law, tending to focus on the establishment of the historical origins of the (European) state as a departure point to explain the gradual development of sovereignty.

Both state-centrism and Euro-centrism are under challenge in international law today and this double challenge, this work argues, is being fruitfully mirrored back into new avenues of research for the study of the history of international law. First, state-centrism has lost some of its momentum in international legal scholarship as a result of the relative decline or demise of the sovereign state as the traditional main actor - and the sole legal subject - of the international legal order. The growing intellectual relevance of the tropes of global governance, ${ }^{5}$ post-national law, $^{6}$ and multilevel governance, ${ }^{7}$ which are marching on the wake of an increasing international institutional proliferation and ongoing regional processes of integration, are a proof of the intellectual leverage of a remarkable post-state centric pull in the field since the end of the Cold War. ${ }^{8}$ This is, furthermore, reflected in reconceptualization of traditional notions of sovereignty, such

\footnotetext{
3 "International Law", Encyclopedia Britannica, accessible at the "MIT Western Hemisphere Project" at http://web.mit.edu/esg-conscience/www/resr/ilaw.pdf. (Last accessed $17^{\text {th }}$ June 2014). The updated edition of the entry "International Law" in the Encyclopedia Britannica provides another perspective on the origins of international in world history and does not contain the quoted reference anymore, see: M Shaw, "International Law" (updated 13-3-2013) Encyclopædia Britannica Online, http://www.britannica.com/EBchecked/topic/291011/international-law (last accessed 17 $7^{\text {th }}$ June 2014) 4 Ibid.

${ }^{5}$ See e.g. D. Kennedy “The Mystery of Global Governance," (2008) 34 Ohio Northern University Law Review, 827

${ }^{6}$ See e.g. N. Krisch Beyond Constitutionalism: The Pluralist Structure of Postnational Law (2010),

7 See e.g. C. Joerges and E.U. Petersmann (Eds) Constitutionalism, Multilevel Trade Governance and International Economic Law (2011)

8 See, e.g. C. Schreuer, "The Waning of the Sovereign State: Towards a New Paradigm for International Law" (1993) 4 EJIL 447
} 
Ignacio de la Rasilla "The Shifting Origins of International Law' 28 Leiden Journal of International Law 3

(Forthcoming, 2015) (Author's unedited versión - please refer to the published version) (c)

as those echoed by the notions of "disaggregated sovereignty" 9 "late sovereignty" 10 or "post-sovereignty"11 in international legal scholarship. This post-state centric pull is in turn fostering new interdisciplinary methodological lenses to the study of sovereignty and the Westphalian paradigm. ${ }^{12}$ Indeed, the emergence of new trans-boundary challenges, the universalization of international human rights standards and the recognition of the growing international relevance of a panoply of non-state actors as subjects of international law and bearers of international rights and obligations ${ }^{13}$ (e.g., the individual, international non-governmental organizations, transnational and multinational corporations, international organizations) ${ }^{14}$ have contributed to the development of a growing number of academic reflections on the role of transnational and non-state law on the international sphere. ${ }^{15}$ This, along with the emergence of functionally distinct technical specialized international legal regimes, ${ }^{16}$ has led to a rethinking of the descriptive and predictive inaccuracy of a "state-dominated understanding of global society“. ${ }^{17}$ Since the early 2000s, this reconceptualization has challenged international legal scholars to revisit their narrative assumptions ${ }^{18}$ and methodological approaches to the history of the discipline - what is often described as the 'turn to history'. ${ }^{19}$

\footnotetext{
${ }^{9}$ A M Slaughter,A New World Order (2004)

${ }^{10}$ See e.g. N Walker 'Late Sovereignty in the European Union' in Neil Walker (ed) Sovereignty in Transition (2003) pp. 3-32

${ }^{11}$ See e.g. N MacCormick, "Sovereignty and after" in H Kalmo and Q Skinner (eds) Sovereignty in Fragments. The Past, Present and Future of a Contested Concept (2011) 151

12 A new "social-science functionalist paradigm" has been put forward by JP Trachtman. This variant of a neo-functionalist approach, ${ }^{12}$ which is based on an inter-disciplinary methodology rooted in new institutional economics (including constitutional economics) and applies different techniques, including, among others, price theory, transaction costs economics, game theory or contract theory, is, indeed, one that accepts that "the state is contingent, and that international law tends to constrain - indeed, to mould - the state on the basis of its functional efficiency". J. P. Trachtman, The Future of International Law, Global Government (2013) at 18.

${ }^{13}$ See e.g. A Clapham, Human Rights Obligations of Non-State Actors (2006)

${ }^{14}$ See e.g. J.E. Álvarez, International Organizations as Law-Makers (2005)

${ }^{15}$ See e.g. P Zumbansen, "Transnational Law, Evolving", J Smits (ed.), Encyclopedia of Comparative Law (2nd ed., 2012), pp. 899-925.

${ }^{16}$ These are partly managed from what D Bethlehem, in his examination of the demise of the "geographic citadel of statehood" considers are the growingly empowered sites of a "technocratic post-Westphalian world" See D Bethlehem, "The End of Geography: The Changing Nature of the International System and the Challenge to International Law", (2014) 25 EJIL 1 at 15. For examples, see pp. 16 and 17.

17 Trachtman, supra note 14 at 10.

18" See, seminally, T. Altwicker and O. Diggelmann, How is Progress Constructed in International Legal Scholarship? (2014) EJIL vol. 25 no. 2 pp. 425-444 at 437.

${ }^{19}$ On the "turn to history" in international law see e.g. R.C.H., Lesaffer, "International Law and Its History: The Story of an Unrequited Love", M Craven, M. Fitzmaurice and M. Vogiatzi (Eds) Time, History and International Law (2006) 27. See also Skouteris, "Engaging History in International Law" (2012), D. Kennedy and J.M. Beneyto (Eds.), New Approaches to International Law: The European and American Experiences 99.
} 
Ignacio de la Rasilla "The Shifting Origins of International Law' 28 Leiden Journal of International Law 3

(Forthcoming, 2015) (Author's unedited versión - please refer to the published version) (C)

These critiques of the state-centric model are coupled with accusations that the classical idealist and realist accounts of the history of international law are profoundly Eurocentric. This critique of Eurocentrism, which had been previously heralded by post-colonial scholarship, has adopted a more confrontational way under the intellectual influence of $C L S$ and post-modernism since the late-90ies. ${ }^{20}$ The study of the history of international $\operatorname{law}^{21}$ has been one of the areas where post-colonial scholarship in international law has impacted received visions of international law in at least two key senses. First, the "contributionist generation"22 opened the classic Eurocentric Western historiography of international law to the pre-colonial experiences of Non-European peoples and regions ${ }^{23}$ and highlighted the "silent contribution" of non-European peoples to the doctrinal development of international law against European claims to Eurocentric universality. ${ }^{24}$ And second, post-colonial approaches have contributed to the field of the history of international law by means of their revisionist historical reading of international law as a tool of imperialist agendas and European domination. ${ }^{25}$ Against this introductory background, this work argues that the post-state centric and post-Eurocentric challenge in international legal scholarship, which coincides with a period of multicultural globalization and rising multi-polarity on the international plane, is currently transforming the traditional Eurocentric and state oriented historiography of international law. Over the last decade, the "turn to history in international law"26, which has recently attracted

\footnotetext{
20 See e.g. introductorily, I. de la Rasilla del Moral "International Law in the Historical Present Tense" (2009) 22 LJIL 629

${ }^{21}$ A. Becker, Eurocentrism in the History of International Law (2012) Peters, A. and Fassbender B. (Eds) Oxford Handbook of the History of International Law, 1034

22 The term is used by J T Ghatti, "Africa and the History of International Law" Peters, A. and Fassbender B. (Eds) Oxford Handbook of the History of International Law, 1034407

${ }^{23}$ R.P. Anand, "On the Influence of History on the Literature of International Law " in RSt MacDonald and DM Johnston (eds) The Structure and Process of International Law: Essays in Legal Philosophy, Doctrine and Theory (1983) 341

${ }^{24}$ An early exponent was C. H. Alexandrowicz, An Introduction to the Law of Nations in the East Indies (16th, 17th and 18th centuries) (1967). See e.g. T.O. Elias, Africa and the Development of International Law (1972) See also Johns, F., Skouteris, T., and Werner, W., "Editor's Introduction: Taslim Olawave Elias in the Periphery Series" (2008) 21. 2 LJIL 289

${ }^{25}$ A. Anghie, Imperialism, Sovereignty and the Making of International Law (2005)

${ }^{26}$ On the "turn to history" in international law see e.g. M Koskenniemi, "Why History of International Law Today?" (2004) 4 Rechtsgeschichte 61. R.C.H., Lesaffer, "International Law and Its History: The Story of an Unrequited Love", M Craven, M. Fitzmaurice and M. Vogiatzi (Eds) Time, History and International Law (2006) 27. See also Skouteris, "Engaging History in International Law" (2012), D. Kennedy and J.M. Beneyto (Eds.), New Approaches to International Law: The European and American Experiences 99.
} 
Ignacio de la Rasilla "The Shifting Origins of International Law' 28 Leiden Journal of International Law 3

(Forthcoming, 2015) (Author's unedited versión - please refer to the published version) (C)

wider attention thanks to the recent publication of voluminous multi-authored research handbooks, ${ }^{27}$ has contributed to foster a number of publishing initiatives in specialized academic journals ${ }^{28}$ and towards the launching of a series of special book collections on the history of international law. ${ }^{29}$ These initiatives, along with the critical mass of recent specialized scholarship ${ }^{30}$ providing a new canon of referential works ${ }^{31}$ and specialized bibliographies $^{32}$ are the best indicators that the history of international law is coming of age as a new field of intellectual inquiry. New historiographical debates in this field, such as the one between contextualist historiography and the critical historiography of international law, bear witness of what E. Jouannet and A. Peters have termed a "renaissance of historical studies in international law". ${ }^{33}$ In the course of the latter debate, it has been convincingly argued that despite the valuable methodological insights and historiographical contributions provided by "contextualism"34 against the ills of anachronism, precursiorism, Whig history and other traditional companions of the history of international law, ${ }^{35}$ contextualism per se - that is, as a method of historiographical inquiry - cannot claim any dogmatic methodological predominance over

\footnotetext{
27 See e.g. Peters, A. and Fassbender B. (Eds) Oxford Handbook of the History of International Law (2012) A. Orakhelashvili (Ed.) Research Handbook on the Theory and History of International Law. 2011.

${ }^{28} \mathrm{See}$, to mention but a few, the "Periphery series" published by Leiden Journal of International Law Fleur Johns, Thomas Skouteris 1 and Wouter Werner "Editors' Introduction: Alejandro Álvarez and the Launch of the Periphery Series" 19 Leiden Journal of International Law 4 (2006) pp 875-877. See e.g recently, Alexandra Kemmerer, "Towards a Global History of International Law? Editor's Note, A Book Review Symposium on Bardo Fassbender and Anne Peters, The Oxford Handbook on the History of International Law" (2014) 25 The European Journal of International Law 1 287-295

${ }^{29}$ See e.g. The Brill's Studies in the History of International Law http://www.brill.com/publications/studieshistory-international-law (last acceded 31 $1^{\text {st }}$ Oct 2014) and, more recently, Oxford Series on the History and Theory of International Law http://ukcatalogue.oup.com/category/academic/series/law/htil.do (last acceded $31^{\text {st }}$ Oct 2014)

${ }^{30}$ For the state of the discipline in 2000 see. I. J. Hueck "The discipline of the History of International Law : New Trends and Methods on the History of International Law" (2001) 3 Journal of the History of International Law (2001) 200

${ }^{31}$ See in particular, M Koskenniemi, "A History of International Law Histories" Peters, A and Fassbender, B., Oxford Handbook of the History of International Law (2013) 943-971

${ }^{32}$ See Oxford Bibliographies of International Law (ed. Anthony Carty) at http://www.oxfordbibliographies.com/obo/page/international-law (last acceded 31st Oct)

${ }^{33}$ E. Jouannet and A. Peters, "The Journal of the History of International Law: A Forum for New Research" 16 Journal of the History of International Law (2014) 1-8 at 2

${ }^{34}$ Q. Skinner, "Meaning and Understanding in the History of Ideas" (1969) 8.1. History and Theory 3.

${ }^{35}$ A must read in this genre is R Tuck, The Rights of War and Peace: Political Thought and the International Order from Grotius to Kant (1999). See also A Brett Changes of State Nature and the Limits of the City in Early Modern Natural Law (2011)
} 
Ignacio de la Rasilla "The Shifting Origins of International Law' 28 Leiden Journal of International Law 3

(Forthcoming, 2015) (Author's unedited versión - please refer to the published version) (C)

critical narratives of international legal history. ${ }^{36}$ The notion of historical "context" is ultimately boundless and subject to unavoidable "choices and evaluations" that are, furthermore, irremissibly conditioned by the present. Moreover, throughout its post2000s' expansion, the history of international law has been maturing beyond the earlier narrow confines of diplomatic history towards a more unashamed embrace of interdisciplinary pollination and an openness to the diversity of national, regional and even trans-civilizational and encounters' based standpoints.

These post-2000 developments should, however, only be seen as an indication of a gradual turning point in the study of the history of international law. Indeed, in order to nurture a new basis for the rejuvenation of the history of international law and its intellectual history, which would effectively counteract the traditional proclivity of the field to gravitate around state-centrism and Euro-centrism, and to open itself fruitfully towards new enriching inter-disciplinary synergies, a number of signposts of the history of international law are examined. The first section points to the foundational effects over the history of international law of the rise of positivism - understood as a method of norm-identification - and the important role played by methodological nationalism ${ }^{37}$ in the modern foundational period of international law. This review is extended by an examination of some the lasting effects that both of them have had over the traditional historiographical state of affairs. This examination indicates that the foundational period of international law bequeathed a lasting double exclusionary bias regarding both time and space in the history of international law, and that the latter cause lies behind the still reiterative focus of many contributions on a series of canonical events and authors to the exclusion and marginalization of others. The second section briefly analyses how this state of historiographical affairs is changing. It does so by pointing to a number of pre2000s intra-disciplinary developments which set the ground for a gradual change of perspective in the evolving study of the history of international law. The second section

\footnotetext{
${ }^{36}$ See M. Koskenniemi, "Vitoria and Us. Thoughts of Critical Histories of International Law" (2014) 22 Rg Rechtgeschichte, pp. 119-138 See also Orford, A., "On International Legal Method" (2013) 1.1. London Review of International Law 166, 170-174 and M Koskenniemi, "Histories of International Law: Significance and Problems for a Critical View" (2013) 27.2. Temple International Law and Comparative Law Journal 215, 229-232.

37 See introductorily A. Wimmer and N. Glick Schiller, "Methodological Nationalism and Beyond: NationState Building, Migration and the Social Sciences" (2002) 2.4 Global Networks 301.
} 
Ignacio de la Rasilla "The Shifting Origins of International Law' 28 Leiden Journal of International Law 3

(Forthcoming, 2015) (Author's unedited versión - please refer to the published version) (c)

also includes a reference to the effects that in a post-Cold War scenario, a neomedievalist pull, a revitalization of post-colonial scholarship on the history of international law and, more recently, of an "international turn in the writing of history" 38 are having in fostering the development of new areas and scholarly tendencies in historical studies in international law. It also examines some of the incipient areas and features of this new scholarship such as the on-going development of globalist historiographical lenses combined with an effort to foster inter and trans-civilizational perspectives into the history of international law as well as the extension of the field towards both the history of non-state actors and the on-going development of the history of particular sub-fields of international law. Finally, the conclusion reflects on some of the tasks lying ahead for the history of international law as a field of new research by providing a series of historiographical signposts.

\section{Revisiting some Historiographical Foundations}

The question of the origins of international law has long preoccupied international legal scholars. ${ }^{39}$ In the classical Western European genealogy, the question of the modern origins of international law is conventionally retraced back to either 1625 , with the publication of Grotius' De lure Belli ac Pacis, ${ }^{40}$ or, to 1648 with the Peace of Westphalia. This is traditionally understood as the etiological (that is, a myth for the origin of things) birthdate of the modern European state-system within a partially secularized postimperial sovereignty-based ius publicum europaeum. Indeed, the orthodox historiography of international law, which delves into the Eurocentric and state-centric roots of international law, has traditionally been almost exclusively focused on the reconstruction of a Western European foundational matrix for an early modern law of nations. This foundational matrix extended through different waves of colonization and was finally universalized as the age of formal empire unfolded towards Africa, the Middle East and South Asia. This was possible thanks to a European imperial expansion which fostered the gradual transition from the jus publicum europaeum to a jus publicum

\footnotetext{
${ }^{38}$ Armitage Foundations of Modern International Thought (2013) at 18.

${ }^{39}$ See e.g. E. Nys, Les origines du droit international (1894).

40 Hugonis Grotii, De Jure Belli ac Pacis, libri tres (1625)
} 
Ignacio de la Rasilla "The Shifting Origins of International Law' 28 Leiden Journal of International Law 3

(Forthcoming, 2015) (Author's unedited versión - please refer to the published version) (C)

universale permeated by the standard of civilization ${ }^{41}$ in the name of la mission civilisatrice from the mid-late 19th century onwards. This historiographical paradigm would be further reinforced by its coincidence with a greater nationalist demarcation of the internal boundaries of the European nation states in the mid-to-late 19th century. This is a historical period where both the professional study of History and of Law at the national level - and with them, of international law and the history of international law ${ }^{42}$ were born in a way that was tied to the European national state-building project. Both have subsequently remained tangled in their development with methodological nationalism. ${ }^{43}$

As far as the dynamics of history making in international law are concerned, both the need to provide solid historical foundations for the European state-centric international order and the project of reconstruction of European national histories in an unitary spirit help account for why the late 19th century and early to mid-20th century's coverage of the early modern-period and classic "founding fathers" of international law usually revolve around the Westphalian period and its immediate pre-foundational stage in the 16th century. This development was, furthermore, fostered by the fact that the mid-tolate 19th century saw the climax of positivism with its symbolic extrapolation of the empirical method to international legal science. The latter, which was put at the service of the enterprise of international legal codification, was aided by the rise of the "scientific" method ${ }^{44}$ across the social sciences in the nineteenth century. The rise of a "scientific legal method" jumped on the bandwagon of the development that, throughout the 19th century, the natural sciences had been experiencing. This was the period of industrial revolution and breakthroughs in Physics, Biology, Medicine, and Zoology, as well as of the development of new technical-applied sciences in transport and communications. This across-the-board prestige of "science" decisively contributed to

\footnotetext{
41 See G Schwarzenberger, "The Standard of Civilization in International Law", (1955) Current Legal Problems 212. See also G. Gong, The Standard of Civilization and the international Society (1984)

${ }^{42}$ M. Koskenniemi, The Gentle Civilizer of Nations: The Rise and Fall of International Law 1870-1960 (2002)

43 For a critique of methodological nationalism "as a key, if not the key feature of the history of the social sciences at large" see D. Chernilo, "The critique of methodological nationalism: Theory and History" (2011) Thesis Eleven, 106.

${ }^{44}$ L. Oppenheim, "The Science of International Law: Its Task and Method" (1908) 2 AJIL 313, 333.
} 
Ignacio de la Rasilla "The Shifting Origins of International Law' 28 Leiden Journal of International Law 3

(Forthcoming, 2015) (Author's unedited versión - please refer to the published version) (c)

the rise of positivism in international law ${ }^{45}$ through the importation of burnished categorical modes of thought to bear scientifically against the influential "Austinian challenge" which, since early in the nineteenth century, had influentially presented international law as merely "positive international morality". ${ }^{46}$ Classificatory schemes were, indeed, designed to be set against the disorder of international relations in order to identify the actual behaviour of sovereign states and the actual laws that those states created through their conduct in an attempt to explain "how international law could be created without a sovereign but without taking recourse in natural law". ${ }^{47}$ In the wake of the spread of international codification and the refinement of a doctrine of international legal sources, "this scientific methodology" would then, as noted by A. Anghie, favour "a movement toward abstraction - a propensity to rely upon a formulation of categories and their systematic exposition as a means of preserving order and arriving at the correct solution to any particular problem." ${ }^{48}$ The scientific approach was increasingly seen as a precondition for the manageable progressive development of international law in a field which would be increasingly oriented to the design of the most possible "scientific" methodology for the practical international norm-identification said to emanate from the will of (mostly Western) sovereign states. The development of such a common scientific and technical vernacular that could tame the propensity to inter-state conflict lies, for instance, as Orford has recently recalled, behind the establishment in 1867 of the Whewell's chair and scholarships in international law. ${ }^{49}$ The spirit of the progressive view, which, at the time, was seen to be channelled through positivism, was invoked by Lassa Oppenheim, the author of the most influential treatise in the English language of

\footnotetext{
${ }^{45}$ See e.g. M. Garcia-Salmones, The Project of Positivism in International Law (2013)

${ }^{46} \mathrm{~J}$. Austin, The Province of Jurisprudence Determined (1832)

47 S Neff, "Jurisprudential Polyphony: The Three Variations on the Positivist Theme in the 19th century' in The Roots of International Law (Ed. P. M. Dupuy and V. Chetail) (2014) at 303.

${ }^{48}$ A. Anghie, "Finding the Peripheries. Sovereignty and Colonialism in Nineteenth Century International Law" (1999) 40 Harvard International Law Journal 1, 21

${ }^{49}$ Orford quotes Marshall, "Whewell Scholarships: Letter 871 to Courtney Stanhope Kenny, 29 April 1907" in J.K. Whitaker (ed.) The Correspondence of Alfred Marshall, Economist: Volume 3, Towards the Close, 1903-1924 (1996) at 155-156 in A Orford, "Scientific Reason and the Discipline of International Law" (2014) 25 EJIL 2369 at 374 . For the British history of international law in the $19^{\text {th }}$ century, see, J Crawford, "Public International Law in Twentieth-century England", in J Beatson and R Zimmmerman (ed) Jurists Uprooted, German-speaking emigrés Lawyers in the Twentieth-century Britain (2004) 681, 688-692 and M Lobban, "English Approaches to International law in the Nineteenth Century, in M. Craven, M. Fitzmaurice and M. Vogiatzi (Eds) Time, History and International Law (2007) pp.65-90 at 70
} 
Ignacio de la Rasilla "The Shifting Origins of International Law' 28 Leiden Journal of International Law 3

(Forthcoming, 2015) (Author's unedited versión - please refer to the published version) (C)

the early 20th century. ${ }^{50}$ Oppenheim, who in 1908 had replaced John Westake as the holder of the Whewell Chair of International law at Cambridge University captured the progressive spirit of positivism in the recently inaugurated American Journal of International Law (AJIL): "for the knowledge of realities enables the construction of realizable truths, in contradistinction to hopeless dreams". ${ }^{51}$

It is against this background of the historically situated apex of nation-state tied positivist method $^{52}$ and the spirit of international codification in the Western world, that the history of international law consolidated a retrospective idealised projection of an ius gentium europaeum premised upon a general recognition of the principles of territorial sovereignty and the classical attributes of state sovereignty into the European past. This period saw the consolidation of the retrospective celebratory reference to the Peace of Westphalia as the mythical birthdate of the modern system of European states or, if preferred, as the European cradle of the legal equality of independent states and the principle of equal sovereignty of European states in both their internal and external facets. Westphalia, thus, became firmly established at this moment as the etiological symbol for an intellectual transition from a natural law dominated world-view towards an emerging voluntary law and the use of the language of law and legality in anchoring the balance of power in interstate relations. It also became retrospectively crystallized as a symbol for the transition from empire to autonomous territorially delimited sovereign orders in a European political order which was by then inaugurating a new "ius publicum europaeum". Importantly enough, Westphalia, also understood as the retrospectively constructed stepping stone between theocracy and a secularist cuius regio eius religio

\footnotetext{
${ }^{50}$ L. Oppenheim, International Law, (1905/1906)

${ }^{51}$ L. Oppenheim, "The Science of International Law: Its Task and Method" (1908) 2 AJIL 333, 355

52 The brief excerpt devoted to positivism in international law is not oriented to present any alternative to it as a method of norm-identification in international law. It should be kept in mind that the interest of the author is historiographical and that, as such, it lies exclusively with making more visible the exclusionary effects that the foundational myths which emerged on the wake of the consolidation in the late nineteenth century of a Western state-centric system have generated in the study of the history of international law. Moreover, because the work of historians of international law has been - and remains - greatly conditioned by what one might call the strong gravitational force of the history of positivism in international law, it was, in the author's view, necessary for the sake of the argument, to briefly examine the context in which the predominance of positivism for international law took hold in the discipline. This is done in order to animate the extension of the gaze of the history of international law into new domains and methods of historical research at a time when both Eurocentrism and state-centrism are under challenge in international law. The author is grateful to the LJIL's board of editors for raising this point.
} 
Ignacio de la Rasilla "The Shifting Origins of International Law' 28 Leiden Journal of International Law 3

(Forthcoming, 2015) (Author's unedited versión - please refer to the published version) (c)

informed by "la raison d'Etat" retrospectively re-ignited the fuse of the European sovereignty-based international society. With it, a Western Eurocentric and state-centric dominant genealogy for the history of international law acquired the global dimension that it still enjoys at the detriment of all other non-Western Eurocentric and non-statecentric historical narratives of the origins and evolution of international law.

A good example of the lasting influential allure of this reconstructive narrative of providing solid foundations for a Eurocentric conception of international law is provided around the 1860s by the figure of Francisco de Vitoria - the "Spanish Classic of International law" who has probably played a greater archetypical role in the consciousness of every generation of international lawyers for the last century and a half. The figure of the Prima Professor of Sacred Theology at the University of Salamanca began to gain international ground in the framework of what P. Haggenmacher has described as the "tournament of the putative founders of international law" at the time. Vitoria had been understood, "during the first part of the 19th century, (...) for most, as a simple name that some evoked without having a true knowledge of his thought" 53 while Hugo Grotius was passed over as "the founder of the discipline and, in principle, its only founder" ${ }^{54}$ It is not, according to Haggenmacher, "until 1860 that one witnesses the slow emergence in prestige of Vitoria in the internationalist milieu in search of the childhood of the discipline" ${ }^{55}$ Indeed, while in 1862, F.E. Cauchy affirmed that Spain "has served as the cradle of the science of the law of nations", 56 it was due to the "discovery of De Jure Praedae in 1864 that the decisive influence of the Spanish scholars, and especially of Vitoria, over the thought of the Dutch jurist-consult became evident" ${ }^{57}$ These early glimpses of the revival of the Seconda Scholastica and the rise in prestige of the work of the Dominican friar Francisco de Arcaya y Compludo, known as Francisco de Vitoria (1483-1547), would find a larger echo and become consolidated in the interwar period. This is a development that may be attributed to J. Brown Scott's role as Editor-in-Chief of

\footnotetext{
53 P. Haggenmacher, "La place de Francisco de Vitoria parmi les fondateurs du droit International" (1988) Actualité de la pensée juridique de Francisco de Vitoria, 29.

54 Ibid., at 28.

55 Ibid., at 30.

${ }^{56}$ E. Cauchy, Le droit maritime international consideré dans ses origines et dans ses rapports avec le progrès de la civilisation (1862) 33.

${ }^{57}$ Haggenmacher (1988) (supra note at 31).
} 
Ignacio de la Rasilla "The Shifting Origins of International Law' 28 Leiden Journal of International Law 3

(Forthcoming, 2015) (Author's unedited versión - please refer to the published version) (C)

the collection of Classics of International Law, a collection which spanned in 40 volumes from 1906 until 1950. This exclusively "Western canon" of classic authors of international law was introduced by Brown Scott, the charismatic force behind the establishment in 1906 the American Society of International Law, ${ }^{58}$ in his General Editor's preface to the first volume. ${ }^{59}$ Brown Scott's words are consistent with the historiographical practice of mid-to-late 19th century and interwar international lawyers, who as D Armitage highlighted, in "seeking historical validation for their ideological projects and infant professions"60 bequeathed international law with "foundation myths retailed by later communities of historians and diplomats, international lawyers and proto-political scientists' ${ }^{61}$

The Eurocentric and state-centric paradigm, which dominated the study of the history of international law throughout most of the $20^{\text {th }}$ century, has bequeathed a double exclusionary bias regarding time and space in the history of international law. This double exclusionary bias regarding time and space in the history of international law has been receding faster, since the early 2000s, in the wake of the "turn to history in international law". However, the reiterative focus on canonical events and authors in the history of international law - to the detriment and marginalization of others - proves that the double exclusionary bias still remains a decisive feature of scholarship in the history of international law. Regarding time, despite certain precursors and progress of new approaches to the study of medieval history of international law ${ }^{62}$, the exclusionary bias is, for instance, apparent in the lack of an extensive analysis on the origins of international law before the mythical constitution of the early modern European state in Westphalia. The traditional state-centrism of international has much to do with this temporal bias evidenced in the limited analysis of the views concerning the origins of international law

\footnotetext{
58 See e.g. I de la Rasilla del Moral, "The Ambivalent Shadow of the Pre-Wilsonian Rise of International Law" (2014) Erasmus Law Review 7, 80-97

59 "It is hoped the series will enable readers as well as specialists to trace international law from its faint and unconscious beginnings to its present ample proportions, and to forecast, with some degree of certainty, its future development into that law which Mirabeau tells us one day will rule the world", J. Brown Scott, "Preface", in T. Erskine (Ed.) The Classics of International Law, Richard Zouche, luris et iudicii fecialis, sive, iuris inter gentes, et quaestionum de eodem explicatio (1911) at 2.

60 D Armitage, supra note 33 at 10.

61 Ibid., at 10.

62 See e..g I de la Rasilla del Moral supra note 26.
} 
Ignacio de la Rasilla "The Shifting Origins of International Law' 28 Leiden Journal of International Law 3

(Forthcoming, 2015) (Author's unedited versión - please refer to the published version) (C)

before the mythical constitution of the early modern European state system in Westphalia and its Spanish precursors in the age of discovery in the literature of the history of international law. Indeed, this historiographical state of affairs owns much, as noted by R. Lessafer, to the traditionally strong purchase of "a chronological state conception of international law in historiographical works which considered Medieval and Ancient periods as not corresponding to international legal system proprio sensu and thus excluded it from attention". ${ }^{63}$ However, even when the current temporal coverage of the history of international law is extended to the period before the early modern European era, this traditionally remains very much tied to Eurocentrism, the other pillar of the traditional historiography. In fact, the occasional temporal extension of the frame of interest of the history of international law is, more often than not, conducted through a search within Western European history of the lasting influence of the Roman civil law tradition and the doctrine of the Christian church over international legal thought. These would be further developed through, respectively, the jus civile and canon law ${ }^{64}$ in the Middles Ages. This is often a search which remains within the parameters of the classic Western tradition through an examination of the Roman ${ }^{65}$ and Greek ${ }^{66}$ origins of the European state-system and its related international legal order. This leads us to the second exclusionary bias still prevalent in the history of international law, that of space. Indeed, most of the research available into the evolution of international law before and post the Westphalian period has been characterized by the fact that European Western international legal history makes for the lion's share of scholarship with still, in comparison, very little in research works available - even in terms of general overviews from non-European views. Although this state of affairs is changing, examples of it still abound in the history of international law. One of the clearest examples of the geographical exclusionary bias, which for C.G. Weeramantry is also proof of the effect of

\footnotetext{
63 That temporal bias is the same one which made Grewe note that "only in the last fifty years has the question of whether a law of nations existed in the Middle Ages been answered in the affirmative by scholars of international legal science". W.G. Grewe, The Epochs of International Law (2000)

$64 \mathrm{~J}$ Muldoon, 'The Contribution of the Medieval Canon Lawyers to the Formation of International Law' (1972) 28 Traditio 483

${ }^{65}$ K H Ziegler "Die römischen Grundlagen des europäischen Völkerrechts" (1972) IV lus Commune 1.

${ }^{66}$ K.-H. Ziegler "Continuity and Discontinuity in European International Law: Ancient Near

East and Ancient Greece" (2011) in T.Marauhn \& H. Steiger (eds.] Universality and Continuity in International Law, 133
} 
Ignacio de la Rasilla "The Shifting Origins of International Law' 28 Leiden Journal of International Law 3

(Forthcoming, 2015) (Author's unedited versión - please refer to the published version) (c)

"generations of prejudiced writing", 67 is the one provided by the Islamic history of international law. ${ }^{68}$ This is a field which has, indeed, been considerably disregarded by the historically dominant Western European international legal tradition and despite the fact that writings on the Islamic law of nations from the early Middle Ages are extensive. However, as it happens for Western European sources, those references are often to be found scattered in general works and books that address other subjects such as the Quoran and its exegesis, the Hadiss and its commentaries and books of jurisprudence. None the less, there is no scarcity of books specifically dealing with the law of nations penned by Islamic legal scholars which antecede Western authors. Among the most often referred, there is Siyar-i-Kebir - a true treatise of the law of nations divided in two volumes - by bin-Hassan-el-Shaybani (804-952), often known as the Islamic Grotius who was translated in English by Khadduri in 1966. Or, to mention but another one, El-Ahkiâmûl-Soulthâniyyeh (Treatise of Domestic and External Public Law) written by Eb-ûl-HassanAlî-ibn-Mohammed-ibn-Khalil-el-Mâwerdi (974-1058). Indeed, for A. Rechid these volumes, along with others produced between the 9th to the 13th-14th century are a clear proof "that Muslim authors have written in this area long before the Christians had published their first books on the topics more or less connected to the law of

\footnotetext{
${ }^{67}$ C.G. Weeramantry, Islamic Jurisprudence: An International Perspective (2nd ed., 1996)
}

68 It should be clear that the reference by the author the neglected study of the Islamic history of international law is exclusively oriented to exemplify one among areas of the history of international law that has been affected by the consequences of the double exclusionary bias bequeathed by the foundational myths of international law. It is beyond the historiographical scope of this work to venture from "what conception of international law does the Islamic history of international law come" or, by the same token, to explore "to which alternative starting points does it point to". It should also be apparent beyond the scope of this historiographical deconstruction of the exclusionary effects bequeathed by the foundational myths of international law to explore "what Islamic international law actually looks like" and "how it does in fact resonate with different conceptions of international law and its origins" neither it is to "show how different conceptions of international law would well give a more prominent place to Islamic International law" or to elaborate on the extent to which "Islamic international law unsettles prevalent conceptions of international law" or "for the same matter how informal mechanisms beyond positivism and state-centrism would resonate with Islamic international law". These are all fascinating questions and the fact that they may rise to surface of the internationalist mind is indicative of the promising venues of intellectual engagement and future research not just with the neglected domain of the Islamic history of international law - referred here only for exemplary purposes - but also with many other neglected domains as the study of the history of international law continue to gradually free itself from the effects of the double exclusionary bias regarding time and space as well as from the associated overlapping and reiterative focus on a series of canonical authors and events to the detriment of others, The author is grateful to the LJIL's board of editors for raising these questions and he is confident that further works in the field of the Islamic History of International Law will engage with them in their appropriate context. See further, De la Rasilla, I. \& Shahid, A. (Eds) History of International Law and Islam (Forthcoming, 2016) 
Ignacio de la Rasilla "The Shifting Origins of International Law' 28 Leiden Journal of International Law 3

(Forthcoming, 2015) (Author's unedited versión - please refer to the published version) (C)

peoples" ${ }^{69}$ One of the lasting side-effects of the narrative displacement, is the existence of a historiographical lacuna regarding the history of Islamic international law which is still barely known by mainstream international lawyers and even by most international legal historians. There are plenty of angles to approach the Islamic history of international law. One of them, which is linked to the intercultural origins of the law of nations refers to what one might call the Spanish-Islamic osmosis which exerted its influence for centuries in the Iberian Peninsula. This Spanish-Islamic osmosis reached its symbolic climax in the cross-cultural roads of Toledo in the times of Alphonse X of Castile. This 13th Century King, called "the Wise", fostered medieval Europe's most comprehensive code of law, the "Siete Partidas", and, by sponsoring Toledo's School of Translators, enriched Latin and the emerging Castilian language (then Spanish) with Islamic and Hebrew sources of knowledge.

The most evident consequence of the double exclusionary bias regarding time and space, ${ }^{70}$ which was bequeathed by the dominant historiographical paradigm in the history of international law, is a reiterative focus on a series of canonical events and authors in the history of international law to the detriment and marginalization of others. This is particularly obvious in the reiterative and overlapping historiographical insistence on the works of "classic" authors such as those belonging to the "Salamanca School" with Francisco de Vitoria at its helm, as well as Hugo Grotius ${ }^{71}$ and, later on, along a classic lists of authors, the Swiss jurisconsult Emmer de Vattel. These, along other members of this genealogy such as F. Suarez, A. Gentili, R Zouche and C.Wolff continue to be reiteratively and telegraphically elevated as exemplary representatives or forerunners of the international legal traditions of natural law, Grotianism and positivism in international law. This historical-theoretical genealogy is an example, as Q. Skinner may have put it, of

\footnotetext{
${ }^{69}$ A Rechid, "L'Islam et le droit des gens." (1937) Recueil de Cours de l'Academie de Droit International de la Haye 60 (1937): 371, 385-386

70 Which could be exemplified by many other examples such as e.g. to mention but one among several highly neglected historiographical areas, the evolution of norms and rules to order inter-community relations among different pre-Columbian peoples in the Americas. See as one of the very few existing references W. Preiser, Frühe völkerrechtliche Ordmungen der aussereuropäischen Welt (1976) See an updated and extended version in French, R Kolb Esquisse d'un droit international public des anciennes cultures extra-europeennes. Amérique precolombienne. Iles Polynésiennes. Afrique Noire. Sous-continent indien. Chine et régions limitrophes (2010)

${ }^{71}$ See the celebrated work by P Haggenmacher, Grotius et la doctrine de la guerre juste (1983, republished 2013)
} 
Ignacio de la Rasilla "The Shifting Origins of International Law' 28 Leiden Journal of International Law 3

(Forthcoming, 2015) (Author's unedited versión - please refer to the published version) (C)

"synoptic histories of thought, in which the focus is on the individual thinkers (or the procession of them)" ${ }^{72}$ The fact that this synoptic history of international legal thought continues to be universally exported in a snippet-like form through standard academic materials and textbooks of international law to readers all over the world could well be seen by the $80 \%$ of the current world population, who are not-Western, as an apparent case of re-exportation of epistemological Eurocentrism by means of the history of international law. To crowd it all, this exportation is done with extremely little contextual historizing to accompany it and a considerable indifference to precursorism or even to 'precursoritis' and its elated anachronistic reading of the present (and the future) in the past by the identification of antecedents of present-day institutions or ideas in earlier historical periods. Fortunately, on the wake of the renovation of historiographical methodologies and of "the turn to history in international law", the canonical European authors of international law are currently being the object of a series of contextualist reinterpretations. ${ }^{73}$ While this re-reading, which has included the figures of H. Grotius, ${ }^{74}$ F. de Vitoria, ${ }^{75}$ and E. de Vattel, ${ }^{76}$ is a positive development still largely in course, the latter does not find parallels for the non-European history of international law.

For Koskenniemi, on the other hand, even the on-going contextualization of great canonical authors and the historizing of the great European theories of international law remains problematic. Koskenniemi believes that "the problem (...) is that it is impossible to write international legal histories - or indeed to participate in international law in present professional or academic institutions - without doing this through a vocabulary and a set of techniques and understandings that are accomplices to a history of European domination" ${ }^{77}$ Against the background of his own realization of the inescapability of epistemological Eurocentrism in the history of international law Koskenniemi attempts to put forward a case for comparative international law by suggesting that "the question

\footnotetext{
72 Skinner (1969) supra note XXX

73 See e.g. Tuck (supra note 28 )

${ }^{74}$ See e.g. M J van Ittersum, Profit and Principle: Hugo Grotius, Natural Rights Theories and the Rise of Dutch Power in the East Indies, 1595-1605 (2006)

${ }^{75}$ For a contextualist perspective of the School of Salamanca, see e.g. A Brett Changes of State Nature and the Limits of the City in Early Modern Natural Law (2011)

76 See also W Rech Enemies of Mankind: Vattel's Theory of Collective Security (2013)

77 Ibid., at 223.
} 
Ignacio de la Rasilla "The Shifting Origins of International Law' 28 Leiden Journal of International Law 3

(Forthcoming, 2015) (Author's unedited versión - please refer to the published version) (c)

remains how to identify and compare autochthonous forms of thinking about intercommunity relations that would not necessarily be subsumable under European legal categories but would stand on their own and thus also provide a wider comparative perspective under which European categories could be examined as equally 'provincial' as others." ${ }^{\prime 78}$ While this insight may be one that is very much worth pursuing especially in view of the temporal effect of the exclusionary bias in non-European histories of international law, it is worthwhile remembering that the provincialization of the history of international law in Europe is very far from being complete. A classic theme like the historiographical contest about the origins and the founding founders of international $\operatorname{law}^{79}$ has become through time an intellectual highway for overlapping and reiterative analysis that are historically tainted by nationalism (in terms of the contribution of international law to nation-building identity myths), religious dogmas (as in the struggle for influence between Catholics and Protestants or/and between Christianity and Islam), 80 methodological concerns (as in the classic confrontation between positivist and natural law perspectives of international law), as well as cultural and geo-political fierce oppositions (as show by the struggle between centre and periphery in the history of international law). ${ }^{81}$ Still today, a renewed study of the different facets and stages through which the classical contest on the founding fathers of international law and debates on the origins of international law have evolved has much to offer to the study of constitutive role of the history of international law in the conformation of particular national European mythologies. This would contribute to the unravelling of half-baked extended perceptions about the history of international law, as well as to the discovery

\footnotetext{
78 M Koskenniemi, "The Case for Comparative International Law" (2011) Finnish Yearbook of International Law 5.

${ }^{79}$ For a recent addition to the line of literature with several contributions addressing the "origin and evolution of the international legal order", see P.M. Dupuy and V Chetail (eds) The Roots of International Law / Les fondements du droit international, Liber Amicorum Peter Haggenmacher (2013)

${ }^{80}$ Compare the seminal role attributed to Bin-Hassan-el-Shaybani who published in the 9th century the Siyar-i-Kebir that is "considered the world earliest treatise of international law as a separate topic" against the publication of the "Tractarum represaliorum" in the Italian Rinascimento where Bartolus de Sassoferrato "famously stated that empire had sovereignty de jure and the city-states sovereignty de facto - a statement which, for some, offers a first theoretical expression in late Medieval Europe of the concept of independent States under a body of norms governing inter-State relations. See further C Weeramantry, Islamic Jurisprudence: An International Perspective, Palgrave Macmillan (1988) at 130 and De Sassoferrato, Bartolus, Tractatus represaliarum (1354) in Consiliorum Bartoli Libri duo (Libri duo) fol. 125r-131r (repr. Rome, II Cigno Galileo Galilei, 1996)

${ }^{81}$ A. Becker Lorca, Eurocentrism in the History of International Law (2012) Peters, A. and Fassbender B. (Eds) Oxford Handbook of the History of International Law, 1034 supra note.
} 
Ignacio de la Rasilla "The Shifting Origins of International Law' 28 Leiden Journal of International Law 3

(Forthcoming, 2015) (Author's unedited versión - please refer to the published version) (C)

of many still to be explored particular national histories and their hidden influence over the course of the history of international law ${ }^{82}$ within Europe itself.

\section{A Changing Historiographical Landscape}

The classical Eurocentric and state-centric historiographical state of affairs with its accompanying double exclusionary bias regarding time and space in the history of international law is, however, in transformation. With the slow receding of the strong gravitational force of this historiographical paradigm, there is, perhaps, also "the view that there is a single, universal international law with a homogeneous history and an institutional-political project" which, is a vision that according to Koskenniemi "emerges from a profoundly Eurocentric view of the world". ${ }^{83}$ This contemporary shift in international legal scholarship is opening new historiographical perspectives at a time when the history of international law is being gradually re-conceptualized to reflect a deeper sensitivity for the transcultural, trans-religious and trans-civilizational aspects of its gradual coming into being, its present and its future. Against this background, this section will first review how a number of earlier intra-disciplinary precursors set the ground for some of the post-2000s developments in the history of international law; and second, point to some of the incipient characteristics of the field of the history of international law which, informed by a maturing historiography, are likely to continue providing direction to future research developments in this area in the years to come.

Whereas an intellectual history of the evolving historiography of international law still remains in its infancy, a telegraphic reference to the precursors of the contemporary change of tide should refer to a number of earlier intra-disciplinary developments. For several decades now, there have been intra-disciplinary developments within the "hitherto neglected field of the history of international law". ${ }^{84}$ These scattered developments set the ground for $21^{\text {st }}$ century's new interest on the historical origins of international law as an intellectual space before the constitution of the traditional

\footnotetext{
82 See e.g. I. de la Rasilla del Moral, In the Shadow of Vitoria - A History of International Law in Spain (Forthcoming, 2015)

${ }^{83}$ Koskenniemi supra note 61 (The Case) at 4

${ }^{84}$ See Lesaffer, supra note $25 /$
} 
Ignacio de la Rasilla "The Shifting Origins of International Law' 28 Leiden Journal of International Law 3

(Forthcoming, 2015) (Author's unedited versión - please refer to the published version) (C)

attributes of state sovereignty. Reference to some of these efforts to extend the history of international law both in space, by extending the geographical boundaries of the field beyond Europe, ${ }^{85}$ and in time, by extending the classically depicted geopolitical origin for a modern (or classical) law of nations before Westphalia, might include a mention to earlier generations of which W. Preiser's works - as well as the work of others such B. Paradisi, ${ }^{86}$ S. Verosta ${ }^{87}$ or W.Grewe - are representative. ${ }^{88}$ For Preiser, who was aware that chronological periodization and geography - or, more broadly, time and space - play a key role in the epochal demarcations (or subdivisions) of the history of international law, the crux of the matter lied with the definition of international law undergirding each chronological periodization. Broadly speaking, Preiser's methodological historiographical re-consideration of the origins of international law developed in two orientations. The first orientation was that of a spatial geographical opening the history of international law towards a greater universalism. In linking the definition of international law to the socio-legal understanding ubi societas inter potestates, ibi ius gentium, Preiser contributed to extend the field of study of medieval international law far beyond Western Europe. In order to do so, W. Preiser, proposed a more relative and universal conception of international law as the law of "several independent political entities that had relations with each other on equal footing and acknowledged that their relations were governed by legal norms." 89 The second and parallel element of the new orientation was to extend the temporal focus before Westphalia in order to highlight "continuity" in the history of international law. Continuity was identified by Preiser to highlight the importance of the period of Western transition for Late Antiquity to the Early Middle Ages. Indeed, for Preiser, despite the lack of a distinguishable international legal order built around the pre-eminence of a single dominant power, this transitional period should be seen as the

\footnotetext{
${ }^{85}$ W. Preiser, Frühe völkerrechtliche Ordmungen der aussereuropäischen Welt (1976) See an updated and extended version in French, R Kolb Esquisse d'un droit international public des anciennes cultures extraeuropeennes. Amérique precolombienne. Iles Polynésiennes. Afrique Noire. Sous-continent indien. Chine et régions limitrophes (2010)

${ }^{86}$ B Paradisi, Storia del diritto internazionale nel medio evo: L'età de transizione (1956)

${ }^{87}$ S. Verosta 'International Law in Europe and Western Asia between 100 and 650 AD' (1964-III) 113 Courses of the Hague Academy 485

88 W. Preiser, Frühe völkerrechtliche Ordmungen der aussereuropäischen Welt (1976) See an updated and extended version in French, R Kolb Esquisse d'un droit international public des anciennes cultures extraeuropeennes. Amérique precolombienne. Iles Polynésiennes. Afrique Noire. Sous-continent indien. Chine et régions limitrophes (2010) 
Ignacio de la Rasilla "The Shifting Origins of International Law' 28 Leiden Journal of International Law 3

(Forthcoming, 2015) (Author's unedited versión - please refer to the published version) (C)

cradle of a number of "international legal features, some of which had an influence on the law for a long time to come." 90 Preiser sought continuity not at the normative levelthat is, not at the level of substantive rules of law-but instead at the deeper and more abstract level of "non-normative elements such as structures, principles and ideas"91 which informed the inner development of the international legal order.

Both parallel intra-disciplinary orientations have been favoured by post-2000s parallel developments under the impact of a more progressive post-state centric pull and postEurocentric pull under the influence in international legal scholarship of the series of phenomena linked to the decline or relative demise of the sovereign state as the traditional main actor of international law and relations, and the related processes of regional economic and political integration in Europe that had been fuelled by the relative new "peripheralization" of Europe in the globalized world stage. First, the temporal factor itself has been enlarged by the effect of a neo-medievalist international legal pull. Within the Western European domain, further research has extended through a series of works that provide a more detailed attention to the intellectual lines of continuity between the early, high and late Middle Ages by focusing, for instance, on the role of canon law in developing the language of international law, ${ }^{92}$ or by examining successive dominant approaches that fleshed out the development of the jus commune tradition since the late Middle Ages, ${ }^{93}$ as well as by extending research into neglected areas through new monumental works on the "Caroligian period". ${ }^{94}$ Research in this area has also led to a more detailed coverage of pre-Westphalian periods in specialized literature ${ }^{95}$ as well as

\footnotetext{
90 Preiser (1964)

${ }^{91} \mathrm{H}$ Steiger "Universality and Continuity in International Public Law" (2011) T. Marauhn and H. Steiger (eds.), Universality and Continuity in International Law 35.

92 See e.g. R H Lesaffer "The Medieval Canon Law of Contract and Early Modern Treaty Law." (2000) Journal of the History of International Law 2 pp. 178-198 building on J. Muldoon, Canon Law, the Expansion of Europe, and World Order. Variorum Collected Studies (1998)

93 Wijffels, Alain. "Early-Modern Scholarship on International Law." In Research Handbook on the Theory and History of International Law. Edited by Alexander Orakhelashvili, 23-60. Cheltenham, UK: Edward Elgar, 2011.

${ }^{94} \mathrm{See}, \mathrm{H}$. Steiger, Die Ordnung der Welt. Eine Völkerrechtsgeschichte des karolingischen Zailtalters (741 bis 840) (2010)

95 See e.g. D. J. Bederman, International Law in Antiquity (2007) Amnon Altman, Tracing the Earliest Recorded Concepts of International Law (2012)
} 
Ignacio de la Rasilla "The Shifting Origins of International Law' 28 Leiden Journal of International Law 3

(Forthcoming, 2015) (Author's unedited versión - please refer to the published version) (C)

in a new generation of handbooks. ${ }^{96}$ Secondly, post-colonial scholarship has contributed to extent the spatial dimension of the research on the history of international law. It has become accepted to distinguish between two generations of scholarship. The first generation emerged began to set the ground by highlighting the contribution of nonEuropean peoples to the development of international law and by opening up the classic Eurocentric Western historiography to the pre-colonial experiences of Non-European peoples and regions. Since the late-90ies, a second generation has enhanced the history of international law as part of a strong critique of international law as a tool of imperialist agendas and European domination. ${ }^{97}$ This is a critique which has fostered the revision of key concepts of the history of international law in the light of the colonial enterprise. Through different generations, which are currently examined under the labels of TWAIL I and TWAIL II, ${ }^{98}$ contemporary post-colonial sensitiveness in international law stressed the existence of a geo-cultural frame, and an epistemology of domination whereby tools of sub-alternization had extended throughout the social sciences - including international law - in different imperial periods. Indeed, for some African critical international scholars such as M. Mutua, the "blotting out of early African history" is part a racist mythology according to which before colonialism "Africans were a tabula rasa in international law". ${ }^{99}$. New-approaches-to-international-law's scholars, who have consistently contributed to enrich the study of the history of international law with new challenging sensitivities and methodologies, ${ }^{100}$ have played an important role in fostering a post-colonial twist to the "historical turn" in international" law.

\footnotetext{
96 See e.g. S. Neff, Justice Among Nations: A History of International Law (2014) See also, among others, S. Laghmani, Histoire du droit des gens: Du jus gentium imperial au jus publicum europaeum. (2004) D. Gaurier, Dominique. Histoire du droit international: Auteurs, doctrines et développement de l'Antiquitié à l'aube de la période contemporaine (2005).

97 A Anghie, Imperialism, Sovereignty and the Making of International Law (2005)

98 See e.g. B.S. Chimni "Third World Approaches to international Law: Manifesto" (2006) International Community Law Review 3

99 For Mutua there cannot be doubt that the denial of African international law is part of a "wilful dehumanization used to justify the continent's subsequent enslavement, colonization and exploitation", a project in which international law "construed as the project of European nations" played a decisive role, see M Mutua. "Review of Africa: Mapping New Boundaries in International Law, Ed by Jeremy I. Levitt" (2010) 104 American Journal of International Law 3, 532-538.

100 T Skouteris "New Approaches to International Law" (2012) A Carty (Ed.) Oxford Bibliographies Online: International Law
} 
Ignacio de la Rasilla "The Shifting Origins of International Law' 28 Leiden Journal of International Law 3

(Forthcoming, 2015) (Author's unedited versión - please refer to the published version) (c)

These two historiographical orientations towards the re-examination of an imagined presovereign space beyond the traditional historiographical Westphalian paradigm, and the extension of its historical geographical scope (both before and after Westphalia) in nonEuropean settings, have been enhanced in post 2000s' international legal scholarship. These historiographical coordinates have moreover contributed to new post-2000s developments which present innovative features. These are incipient characteristics within the field of the history of international law which, informed by a maturing historiography, are likely to provide direction to future scholarly developments in the years to come. Among the latter, one can, firstly, identify topical extension towards the history of non-state actors and the development of the history of particular sub-fields of international law. Indeed, the history of international law is finding new channels of scholarly exploration, such as social movements, collective identities, cultural and intellectual trends, individuals - including, but not limited, to international legal scholars and international judges ${ }^{101}$ - and a panoply of other non-state actors. The development of histories of sub-fields of international law has moreover advanced thanks to the ongoing fragmentation of international law. The emergence of sub-disciplines is also leading to the production of a growing number of thematic histories of international legal institutions and to an on-going new historiography of particular specialized branches of international law. These include, to mention but a few, a new intellectual history of international institutional law, ${ }^{102}$ the vibrant development of the history of international criminal law, a new history of international courts and tribunals (that looks beyond successful projects into histories of short-lived, aborted or failed international courts and tribunals), and the introduction of polemicists/revisionist contributions (such as the one heralded by S Moyn) ${ }^{103}$ to the history of international human rights. Two further contemporary characteristics of the field of the history of international law today are worthwhile mentioning. These are, firstly, the development of globalist historiographical lenses combined with an effort to foster inter and trans-civilizational perspectives into

\footnotetext{
${ }^{101} \mathrm{~A}$ case in point is, perhaps, that the emergence of literature around the life and works of $\mathrm{H}$. Lauterpacht for the last 10-15 years. See, among many other contributions, E. Lauterpacht, The life of $\mathrm{H}$. Lauterpacht (2012).

102 See e.g. J Klabbers, "The Emergence of Functionalism in International Institutional Law" (2014) 25 EJIL 3,645

103 S Moyn The Last Utopia (2010)
} 
Ignacio de la Rasilla "The Shifting Origins of International Law' 28 Leiden Journal of International Law 3

(Forthcoming, 2015) (Author's unedited versión - please refer to the published version) (C)

the history of international law. ${ }^{104}$ Indeed, on the wake of the global turn in social sciences, a global history of international law ${ }^{105}$ and a new legal-historiographical expertise on "global perspectives" are gaining momentum. This is, furthermore, influencing the study of the Western European history of international law. For T. Duve, who has tackled the trend from the perspective of the development of a new European legal history, the latter "means to envision a legal history that is able to establish new perspectives, either through opening for different analytical concepts or by fusing them with the own tradition, by tracing worldwide entanglements or by designing comparative frameworks which can shed light on unexpected parallel historical evolutions". ${ }^{106} \mathrm{~A}$ second characteristic feature of the incipient scholarship is the greater interdisciplinary porosity of the study of the history of international law which blends legal theory, international relations theory and its historical discourse, legal history and the history of ideas and political thought. Indeed, the history of international law is becoming more fruitfully permeable to other scholarly developments occurring within a larger multidisciplinary canvas that includes new research in international relations, international history as well as international intellectual history. The effects in neighbouring fields, as well as international law itself, of a series of "turns - linguistic, historiographical, transnational and cultural" to name but a few of them - have led to what D. Armitage has termed a "self-consciously new international history". ${ }^{107}$ This is one which departs from the "more traditional history centred on the archives and activities of states and their formal agents"108 and from the traditional role of the history of international law as the handmaiden at the service of norm-identification. Moreover, the influence of the "international turn in the writing of history" ${ }^{109}$ which is, according to Armitage "perhaps, the most transformative historiographical movement since the rise

\footnotetext{
104 T Marauhn and H. Steiger, (eds) Universality and Continuity in International Law. (2011) Onuma, Y. "When Was the Law of International Society Born? An Inquiry of the History of International Law from an Intercivilizational Perspective." Journal of the History of International Law 2.1 (2000): 1-66. For precedents, see Verosta, Stephan. "Regionen und Perioden der Geschichte des Volkerrechts." Osterreichische Zeitschrift für Offentliches Recht und Volkerrecht 30 (1979): 1-21.

${ }^{105}$ E.g. A Kemmerer, "Towards a Global History of International Law? Editor's Note" (2014) 25.1 EJIL, 287.

106 T Duve, "European Legal History - Global Perspectives" (2013) Working paper for the Colloquium 'European Normativity - Global Historical Perspectives' (Max-Planck-Institute, September, 2nd - 4th, 2013) No. 2013-06 accessible http://ssrn.com/abstract $=2292666$

${ }^{107}$ Armitage, Foundations (2013) supra note 33 at 6

108 Ibid.

109 Ibid., at 18 .
} 
Ignacio de la Rasilla "The Shifting Origins of International Law' 28 Leiden Journal of International Law 3

(Forthcoming, 2015) (Author's unedited versión - please refer to the published version) (C)

of social history in the 1960 s and the linguistic turn in the $1970 s^{\prime 110}$ is leading to new synergetic forms of communication between historians of international law and transnational historians, comparative historians and global historians as they tackle the question of "how should contemporary historians approach the challenge of writing global histories for a self-consciously global age?". ${ }^{111}$ This question acquires an almost normative dimension in a field such as that of the history of international law. One of the greatest lessons that the study of the history of international law has bequeathed historians of international law with is precisely that every new epoch reshapes the history of international law in its own image.

\section{Conclusion - Task Ahead, Signposts.}

In taking the helm of the Journal of the History of International Law in 2014, E. Tourme Jouannet and A. Peters, its new co-editors-in-chief, have convincingly spoken of a "renaissance of historical studies in international law". ${ }^{112}$ They have highlighted "how historians of international law today no longer settle for the classical content of earlier accounts, but look instead to re-work a domain which they deem highly fertile - provided it is renewed". 113 One of the greatest potentialities of the on-going nurturing of a "renewed domain" in the history of international law ${ }^{114}$ is that of providing international legal scholars and students of international law with the possibility of continually "refreshing" their perspective of the role of international law on the evolving stage of international affairs in the $21^{\text {st }}$ century. Looking back to the past of the discipline may, once again, provide direction in that regard. Indeed, in the early 1900s, barely 20 years since the extension of the study of international law to seven universities other than that

\footnotetext{
110 Ibid.

111 Ibid.

${ }^{112}$ E. Jouannet and A. Peters, "The Journal of the History of International Law: A Forum for New Research" 16 Journal of the History of International Law (2014) 1-8 at 2

113 Ibid., at 3.

114 The year 2014 saw also the birth of another initiative aimed at rejuvenating the field of the history of international law. The ESIL's interest group on the History of International Law (IGHIL) which came to life in 2014 "animated by an all-inclusive ethos of infinite curiosity", declared among its purposes that of seeking "to stimulate research on the history of international law in all parts and regions of the globe throughout different historical epochs while contributing to foster ever-higher standards of academic excellence in the field". The website of the ESIL's IGHIL is available at http://esilhil.blogspot.co.uk/ (last visited $15^{\text {th }}$ Jan. 2015)
} 
Ignacio de la Rasilla "The Shifting Origins of International Law' 28 Leiden Journal of International Law 3

(Forthcoming, 2015) (Author's unedited versión - please refer to the published version) (C)

of Madrid, ${ }^{115}$ A. Sela y Sampil, a member of the first Spanish professional generation of professors of international law, ${ }^{116}$ wrote about the role of the history of international law in the teaching methods employed in an international law's classroom in Western Europe:

"In public international law I have predominantly attempted to assist the development of the intelligence and the skills of students by transforming the class-room in a true exercise of thought and by relating it to natural law, political law, geography and history (...)The subject matter allows the implementation of this procedure as few others. The indeterminacy and vagueness of the positive law of peoples; its undoubted underdevelopment when compared to other legal branches; the need to overcome through vigorous efforts of the mind the sadness and pessimisms of the present state of international politics (...) There is no code chaining us, obliging us to follow the exegetic procedure, not any writer whose authority cannot be disputed or rules consecrated by use that would not admit modification: nothing interferes with the free flight of the intelligence" 117

When 115 years have elapsed since these words were published, it would be safe to assume that Sela, who wanted to make their students "Künstler im Lernen" ("artists in the art of learning") would have been surprised to find out that the history of international law does not currently have any place in the teaching curriculum in almost any part of the world. ${ }^{118}$ It is, indeed, particularly surprising in an area of research that

\footnotetext{
115 Diccionario de la Administración Española, Apéndice de 1883, pp. 416-421. Further, I de la Rasilla del Moral, "El estudio de la historia del Derecho internacional en el corto siglo XIX español", (2013) 23 Rechtsgeschichte, 48-65. In English, I de la Rasilla del Moral "The Study of the History of International Law in the Short Spanish Nineteenth Century" (2013) 13.2 Chicago-Kent Journal of International and Comparative Law 122

116 The terminology "first professional generation" comes from M. Koskenniemi, The Gentle Civilizer (supra note 32)

117 A Sela y Sampil «Los procedimientos de enseñanza en la Facultad de Derecho internacional de la Universidad de Oviedo: Derecho Internacional Público y Derecho Internacional Privado», Boletín Oficial de la Institución Libre de Enseñanza, XXVI (1902), núm. 509, pp. 223-234, en p. 223.

118 See specially Milos Vec, "National and Transnational Legal Evolutions - Teaching History of International Law" in Kjell A Modeer and Per Nilsen, (eds) How to Teach European Comparative Legal History (Juristförlaget i Lund, 2011) pp. 25-38 See also Tourme Jouannet \& Peters, noting how “An informal survey of many colleagues worldwide shows that the teaching of the history of international law remains marginal in most countries, especially and above within the internationalist academic world", op. cit. supra 90 at. 3
} 
Ignacio de la Rasilla "The Shifting Origins of International Law' 28 Leiden Journal of International Law 3

(Forthcoming, 2015) (Author's unedited versión - please refer to the published version) (c)

produces a growing number of Ph.D. dissertations every year that the didactic pendulum had completely swung to the other extreme. ${ }^{119}$ Sela y Sampil was a member of the Institution of Free Teaching (Institucion de Libre Ensenanza (ILE) created in Spain in 1876 against the obscurantism of the official curriculum under the inspiration of this starkly modern educational creed:

The professor has no other criterion than his own conscience; study no other method than that which is dictated by reason; truth, no other system than that born out of nature; thought, no other school than free research; scientific life, in sum, no other guide, no other principle than an inquiry alien to any spirit of exclusivism, to any narrow sense of sect. 120

The educational spirit of ILE and the commitment to make students "artists in the art of learning" can still inspire new research on the history of international law as well as, importantly, to horizontally enrich the international legal curriculum of law schools in today's increasingly global classrooms of international law with the fruits of a field which argues "more than ever for a plurality of visions of the history of international law". ${ }^{121}$ However, those considering to embark in the adventure of generating new research on the history of international law may ponder seven historiographical remainders - not a map, but, perhaps, a compass. First, the new research on international law would need to come to terms with the abundance of "historical absurdities" generated by the "mythology of doctrines" 122 in the field of history of international law. These, as Skinner wrote about the history of political thought more than four decades ago, are evidenced by "the tendency to search for approximations to the ideal type (that) yields a form of non-history which is almost entirely given over to pointing out earlier "anticipations" of later doctrines, and to crediting each writer in terms of this clairvoyance". ${ }^{123}$ Another example of the presence of "historical absurdity generated by the methodology of the history of ideas" in the history of international law is the "endless debate - almost wholly

\footnotetext{
119 See on the teaching of the history of international law nowadays, M Vec,"National and Transnational Legal Evolutions - Teaching History of International Law" (2011) K ̊ Modéer \& P. Nilsén (eds.), How to Teach Comparative European History, 25.

120 "Memoria de 1877" (1877). I Boletín de la Institución Libre de Enseñanza 21

121 Tourme Jouannet \& Peters ... op. cit. at. 3

122 Skinner (1969) supra note, at 10

123 Ibid. at 11.
} 
Ignacio de la Rasilla "The Shifting Origins of International Law' 28 Leiden Journal of International Law 3

(Forthcoming, 2015) (Author's unedited versión - please refer to the published version) (c)

semantic, though posing as empirical - about whether a given idea may be said to have "really emerged" at a given time, and whether it is "really there" in the work of some given writer". ${ }^{124}$ Second, new research on international law would also need to be wary of the existence of an extremely strong doctrinal normative pull in the field. Indeed, one cannot but agree with the appraisal that history of international law "is intensely internalist" in the sense that it often consist, as highlighted by Katz Cogan of "histories by lawyers seeking the antecedents of contemporary law and the profession, using the methods and materials that lawyers typically employ". ${ }^{125}$ In facing this state of affairs, new research on the history of international law should, indeed, weight the risks of being co-opted (and that despite what Tourme Jouannet and Peters had called its "certain decline") by "the methodological primacy of technicism (doctrinalism) and pragmatism in international legal scholarship." ${ }^{126}$ Third, new research on the history of international law should keep the history of international law open to literature in other disciplines. Because of the traditional interdisciplinary pollination of the history of international law, the ethos of research on the history of international law should be interdisciplinary. It should remain, as such, fruitfully open to a constructive dialogue with related fields, such as transnational history, which is currently expanding research areas. ${ }^{127}$ However, while an exploration of the transnational history of international law is a field particularly ripe for a dialogue between international lawyers and transnational historians, comparative historians and global historians, a greater and renewed investigation of the particular national histories of international law should not become the baby that is thrown out with the bathwater. In a world where the "communities of fate" that the nation-state embody are gradually giving place to the perception of the existence of a "global community of fate", and thus of a global history of international law for a global age, it may be important to remember that there may be a plus for scholars of the history of international law to engage with each author's own more familiar histories of international law. Fourth, new research on the history of international law should keep

\footnotetext{
$124 \mathrm{Ibid}$, at 12 .

125J. Katz Cogan. "Book Review of B Fassbender and A Peters (Eds.). Oxford Handbook of the History of International" (2014) 108.2. American Journal of International Law, 10.

126 Tourme Jouannet and Peters, op.cit. at 2.

127 See e.g. A.C. L. Knudsen and K. Gram-Skjoldager" Historiography and narration in transnational history" 9.1. Journal of Global History (2014) 143
} 
Ignacio de la Rasilla "The Shifting Origins of International Law' 28 Leiden Journal of International Law 3

(Forthcoming, 2015) (Author's unedited versión - please refer to the published version) (c)

in mind the need to contribute to a much larger bibliographical basis both geographically and temporally for international law in world history ${ }^{128}$ by being aware of the entrenched character of the double exclusionary bias bequeathed by state-centrism and eurocentrism to the history of international law. This shall help to foster the analytical challenge to the shaky historical foundations of the regional particularism lurking behind claims of European universalism in traditional scholarship and to contribute to highlight larger universal origins and cross-cultural influences in its development. ${ }^{129}$ Fifth, the need to be, as Koskenniemi has noted, methodological aware of the relevance of "choices of scope and scale"130 in the research on the history of international law should not lead to methodological or intellectual paralysis. Instead that same awareness can further empower a greater will to explore the history of international law through new narrative styles, more fluid and smoother, unabashedly explorative at times; a style which should not renounce the less trodden paths of the history of international law. History should be put at the service of generating a stimulating - and ideally also transforming - intellectual experience in the mind of the educated reader and the history of international law should not settle for anything less - all History is also story-telling. Sixth, new research on the history of international law should be at least a little wary of the pitfalls of grandiose overtheorizing. For all the healthy "self-questioning"131 that the incipient matureness of a discipline is bound to bring with it, there is the risk of asphyxiating the renovation of the field if the new research on the history of international law falls victim to excessive theorizing about its history over history-of-international law writing itself. It may, indeed, be worthwhile recalling, as E.H. Carr noted, that "History is the historian's experience. It is "made" by nobody save the historian: to write history is the only way of making it" ${ }^{132}$ This is, indeed, precisely why, last but not least, those engaging with the transformative exercise of tearing the "seamless web" 133 of the History of international law should fight

\footnotetext{
128 See Katz Cogan, supra note at 9 highlighting the "lack of a substantial secondary literature" (...) "especially if one is interested in a global perspective".

129 See A Becker Lorca, Mestizo International Law (2014)

130 See Koskenniemi supra note 5, 233 et al.

131 Tourme Jouannet and Peters, op.cit. at 5.

${ }^{132}$ E.H. Carr, What is History? (2 ${ }^{\text {nd }}$ ed. 1987), p.22 quoting M. Oakeshott, Experience and Its Modes (1933), p. 99.

133 The expression is from F Pollock and F. W. Maitland, The History of English Law, 2nd. Ed. (1898) at 1. "Such is the unity of all history that everyone who endeavours to tell a piece of it must feel that his first sentence tears a seamless web".
} 
Ignacio de la Rasilla "The Shifting Origins of International Law' 28 Leiden Journal of International Law 3

(Forthcoming, 2015) (Author's unedited versión - please refer to the published version) (C)

for their own voice so that others may be able to rely (but not too much) on the truth of what it can convey. This is the ultimate pre-condition for the collective enterprise of the new research on the history to international law: to find, under the protecting tutelage of Janus, its own place in the house of Clio. 